\title{
Opinion
}

\section{The role of philosophy in medical practice}

\author{
GEORGE P. CHROUSOS ${ }^{1}$, IOANNIS N. MAMMAS ${ }^{1-3}$ and DEMETRIOS A. SPANDIDOS ${ }^{2}$
}

\author{
${ }^{1}$ First Department of Paediatrics, University of Athens School of Medicine, 11527 Athens; ${ }^{2}$ Laboratory of Clinical Virology, \\ School of Medicine, University of Crete, 71003 Heraklion; ${ }^{3}$ Paediatric Clinic, Aliveri, 34500 Island of Euboea, Greece
}

Received July 22, 2019; Accepted August 26, 2019

DOI: $10.3892 /$ etm.2019.7944

'The best doctor is also a philosopher'

Galen

Approximately 2,500 years ago, at the time of Pericles, a great human civilization peaked in Athens, the city of Athenian democracy. This civilization, which has had a great impact on the modern world, was based on ancient Greek principles, ideas and core values, including moderation, liberty, democracy, justice and the need to use reason to interpret the physical laws of the cosmos. The same civilization founded the sciences as they are known today, initiated evidence-based medicine, promoted the letters and advanced the fine arts, including drama theatre.

Astronomy, mathematics and medicine had already been developed by the Babylonians, Egyptians and others, many centuries before the Greeks. What made the real difference was the development of the field of philosophy and the implementation of its principles in real life (1). Early Greek philosophy related to cosmology was already developed in the pre-Socratic era, while philosophy regarding the nature of man was initiated by Socrates and further developed by Plato and other Greek philosophers, including Aristotle, Plato's best student, Zeno, the founder of the Stoic School, and Epicurus, the originator of the Epicurean School. At a walking distance from the Acropolis lies Plato's 'Academy', one of the most well-known schools of philosophy in the ancient world. Philosophy was a pivotal creation of Greek civilization and a fundamental achievement of the human mind.

If philosophy was what made the difference in the Athenian civilization, can we say that the philosophy of medicine also made a momentous difference in medicine? The answer is: Yes. The Hippocratic Oath is the most significant medical and ethical legacy of Hippocrates of Cos, and its tenets are still pertinent (2). To honour and respect our medical teachers

Correspondence to: Professor Demetrios A. Spandidos, Laboratory of Clinical Virology, School of Medicine, University of Crete, 71003 Heraklion, Greece

E-mail: spandidos@spandidos.gr

Key words: philosophy, Paediatric Virology, medical education, Aristotle
('To hold my teacher in this art equal to my own parents'), to forbid practicing euthanasia ('Neither will I administer a poison to anybody when asked to do so, nor will I suggest such a course'), and to maintain confidentiality of the medical examination ('Whatsoever I shall see or hear in the course of my profession, as well as outside my profession in my intercourse with other people, I will hold all these to be holy secrets'), are all philosophical ethical principles.

Modern Western medicine based on cost-effectiveness, public and private healthcare insurance systems and limited financial resources, underlines the importance of medical philosophy in the practice of medicine by contemporary health professionals (3). Of course, robust scientific knowledge is a sine qua non of practicing effective medicine; however, without understanding and incorporating the key principles of medical philosophy, health professionals might practice unprincipled, potentially unethical and even damaging medicine. Evidence-based medicine is also grounded on medical philosophy (4). There is a wealth of medical knowledge, which is essential for the practice of medicine; however, how this knowledge is interpreted and applied is equally or more important. To practice evidence-based medicine is both a practical and a philosophical decision. Thus, philosophy is a great companion of medicine, as it is of every science or art. In addition, medicine is not just a science, but a combination of science and art, their common goal being alleviating human suffering.

Without any doubt, medical education should include the teachings of medical philosophy. Are there currently courses dedicated to the Hippocratic Oath and the ethical principles of medicine included in the medical school curricula? Probably not, at least in a systematic way. The principles of medical philosophy could be taught in an auditorium with lectures and presentations; however, the primary site of such crucial education of medical students and trainees is the bedside, during their direct practice of medicine and ward-based training (5). Unfortunately, as new knowledge is exponentially increasing, and while time available to medical practitioners is decreasing, the priorities of medical education focus primarily on technical medical knowledge, neglecting its ethical philosophical component. Contemporary teaching frequently highlights endless details from the basic sciences, molecular medicine and the mechanistic pathophysiology of diseases, without 
distinct teaching as to how to apply this knowledge in the clinical practice in a compassionate and humane fashion (6).

Is current teaching of medical philosophy sufficient? Doubtful. What is truly required is the implementation of the principles of medical philosophy in everyday clinical practice. Are the principles easily employed in real life? This is also doubtful. When Plato was due to retire from the leadership of the Academy, he chose Speusippus, his nephew, rather than Aristotle, his best student, as its leader (7). Due to this fact, Aristotle left Athens for Asia Minor and later for the island of Lesbos and the Macedonian city of Pella, where he taught Alexander the Great. Even when he returned to Athens, about 12 years later, and Speusippus had already died, again he was not chosen for the leadership of the Academy. Despite this, in the ensuing years, he founded his own school, the Lyceum, and became known as the greatest philosopher of the ancient Greek world.

Plato's example shows us the difficulty that this idealist teacher of philosophy had in implementing his philosophical principles in real life. Plato had described his ideal 'politeia' of isonomia and equality, and had talked about the core human virtues, the value of truth, and the need for dialogue. He was always looking for the best in both persons and societies. Unfortunately, however, his decision on his succession may have been based on nepotism. This was in contrast with his teachings, and was interpreted by later scholars as the result of either the strictly enforced Athenian legal policy or the social corruption of the Athenians after the loss of their freedom to the Spartans in the Peloponnesian War (8).

The implementation of medical philosophy by health professionals is indeed a difficult, yet essential task. Life principles should not remain theoretical, but instead should be incorporated into real life and applied in everyday clinical practice. The teaching of medical philosophy to health professionals is undoubtedly fundamental, and its implementation in clinical practice is of the highest moral and societal significance. When philosophical principles are properly applied in medicine, clinical practice becomes optimal for the benefit of the practitioner, the patient and society at large.

\section{Acknowledgements}

This article is published in the third supplement issue of the Experimental and Therapeutic Medicine, which is dedicated to Paediatric Virology. This edition is performed in the context of the ' $5^{\text {th }}$ workshop on Paediatric Virology' (Sparta, Greece, October 12, 2019) organized by the Paediatric Virology Study Group (PVSG) and supported by the Department of Clinical Virology of the University of Crete School of Medicine and the First Department of Paediatrics of the University of Athens School of Medicine. The authors would like to thank all the members of the PVSG for their valuable comments and corrections. The authors would also like to thank Dr Melpomeni P. Kountouri (Geneva, Switzerland), Dr Anastasia Stouraiti (London, United Kingdom) and Mr. George D. Karapas (Adelaide, Australia) for reviewing this article.

\section{References}

1. Russell B: A History of Western Philosophy. In: Ancient Philosophy, Part II. Socrates, Plato and Aristotle. Book One. Chapter XXII. Simon and Schuster, New York, NY, 1972.

2. Hippocrates: Oath (Orkos). In: Hippocrates, Apanta 1. Kaktos Editions, Athens, 1993 (In Greek).

3. Mammas IN and Spandidos DA: The future of medical education in neonatology, paediatrics and paediatric virology: An interview with Professor Alan Michael Weindling, Professor of Perinatal Medicine at the University of Liverpool. Exp Ther Med 16: 2805-2808, 2018.

4. Isaacs D: Evidence-based medicine. J Paediatr Child Health 50: 579-580, 2014.

5. Mammas IN and Spandidos DA: The philosophy of paediatric teaching: An interview with Dr Nikolaos Myriokefalitakis, former Clinical Director of the 'Penteli' Children's Hospital in Athens (Greece). Exp Ther Med 16: 2799-2802, 2018.

6. Mammas IN, Spandidos DA and Weindling AM: The future of paediatric education. Exp Ther Med 16: 2803-2804, 2018.

7. Diogenes Laertius V: Diogenes Laertius. Apanta 2. Kaktos Editions, Athens, 1994 (In Greek).

8. Chroust AH: Speusippus succeeds Plato in the Scholarchate of the Academy. Revue des Études Grecques, Année, pp338-341, 1971.

This work is licensed under a Creative Commons Attribution-NonCommercial-NoDerivatives 4.0 International (CC BY-NC-ND 4.0) License. 